International Journal of Linguistics, Literature and Translation

ISSN: 2617-0299 (Online); ISSN: 2708-0099 (Print)

DOI: $10.32996 / \mathrm{ijllt}$

Journal Homepage: www.al-kindipublisher.com/index.php/ijltt

IJLLT

\title{
The Linguistic Landscape of Zhuhai: A Study of the Use of English Signs in the Public Place
}

\author{
Luo Yibu' $8(D)$ and Ma Junjie ${ }^{2} \mathbf{D}(\mathrm{D})$ \\ ${ }^{1}$ Postgraduate student of the University of Melbourne, Parkville, Victoria, Australia \\ ${ }^{2}$ Postgraduate student of the University of Edinburgh, Edinburgh, United Kingdom \\ $\triangle$ Corresponding Author: Ma Junjie, E-mail: s2168595@ed.ac.uk
}

\begin{tabular}{|c|c|}
\hline ARTICLE INFORMATION & ABSTRACT \\
\hline Received: August 12, 2021 & As a window city for China to face internationalization, Zhuhai is quite suitable for \\
\hline Accepted: September 07, 2021 & linguists to look into Expanding Circle Countries' English settings. Bilingual landmarks \\
\hline Volume: 4 & indicate the use of English in the local public sphere and the degree of the popularity \\
\hline Issue: 9 & of English. This study investigated the current situation of English in Zhuhai from two \\
\hline DOI: 10.32996/ijllt.2021.4.9.9 & $\begin{array}{l}\text { academic fields: linguistics landscape and language policy. The two types of language } \\
\text { policy: the top-down model and the bottom-up mode, are used in the analysis of }\end{array}$ \\
\hline KEYWORDS & Zhuhai sociolinguistic phenomenon. An analysis from the language policy perspective \\
\hline $\begin{array}{l}\text { Linguistic landscape, language } \\
\text { policy, the top-down model, the } \\
\text { bottom-up model, English signs }\end{array}$ & $\begin{array}{l}\text { reveals how the linguistic landscape has been interpreted from diversified dimensions } \\
\text { as both a concept and a practice. The study evinces that the different target tourists } \\
\text { and the various functions of facilities are two influential factors in the advancement of } \\
\text { Zhuhai's English signage. }\end{array}$ \\
\hline
\end{tabular}

\section{Introduction}

As a considerable area of sociolinguistic research, linguistic landscape (LL) is a topic that has received increased interest in recent years. LL plays an essential role in the ideological construction of multicultural societies and thus can act as a marker for linguists studying different language community statues (Shohamy, 2006). Though some previous studies have confirmed that LL is beneficial in assisting linguists' research of multicultural context in Western countries and Hong Kong, empirical studies on the public use of English in mainland China is fairly limited, and seldom researchers currently utilized the theories of LL to investigate the use of English as a foreign language in mainland China (Cheung, 2018; Raos, 2018; Song, 2019). Accordingly, the present study aims to fill in the research gap by conducting a study in a southern Chinese city to investigate English signs' function in the public space.

Zhuhai, a special economic zone at the forefront of the reform and opening up of mainland China, is an ideal model window to examine the impact of English on public places. Zhuhai is a bridgehead for many Hong Kong business firms and foreign investors in mainland China. As a developed city located on the west bank of Pearl River Delta, over the past four decades, to cater to the needs of foreign investors, the government of Zhuhai has gradually formulated their language policy to promote the use of English signs in public places. Thus, by combining analysis of social and commercial settings in Zhuhai and investigating Zhuhai's Chinese and English bilingual signs, this current project attempts to increase our understanding of the use of English in mainland China.

\section{Research questions and significance}

a. What is the context in which English signs are used in public places in Zhuhai?

b. What factors influence the use of English in public places in Zhuhai?

According to the theory of Kachru's Three Circle of English, countries across the globe can be classified into three circles depending on different institutional roles of English: Inner Circle English, Outer Circle English, and Expanding Circle English. The present study may shed light on the efficacy of using LL to analyze the promotion of the use of English in public spaces, particularly in the context

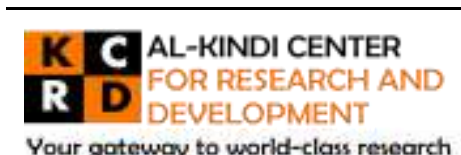

Your gateway to world-class research

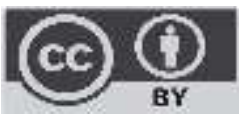

Published by Al-Kindi Center for Research and Development, London, United Kingdom. Copyright (c) the author(s). This open access article is distributed under a Creative Commons Attribution (CC-BY) 4.0 license 
of the Expanding Circle countries, such as China. This study is impactful in two ways: Firstly, it will allow the government of Zhuhai to gain an increased understanding of the current situation so they can implement effective language policies; and secondly, researchers may benefit from knowing the degree of influence of using English on Chinese public spaces. This study contributes to the field of LL by addressing the outstanding lack of investigation into Expanding Circle counties like China, as previous studies have mainly focused on Inner and Outer Circle states. By putting the theoretical foundations of LL into practice, this study provides an insight into how cultural background can be reflected by the use of English in China. Therefore, the analysis of LL theories in the project would be closely connected with Zhuhai government's multilingual policy.

\subsection{Linguistic landscape}

Generally, Linguistic Landscape (LL) refers to the 'visibility and salience of languages on public and commercial signs in a given territory or region' (Landry \& Bourhis, 1997, p. 23). Other researchers such as Shohamy (2006) defined LL as the domain within a language or particular language objects that are visible in public. Examples of LL include roadside brand advertisements, store signs, store loyalty cards, institution names, place titles, etc. LL research focuses on exploring the symbolic function of language signs and investigating how various languages in the real environment manifest power relations, identity, and ideology (Shang $\&$ Zhao, 2014). In researchers' view, LL may also be regarded as a written linguistic phenomenon that occurred in the public environment or a kind of language symbolization use in society.

In recent years, a growing number of researchers have started focusing on the academic significance of sociolinguistics. Järlehed (2017) stressed that LL studies can derive information from a contextualized investigation of particular sign genres, with these semiotic resources providing information regarding complicated cultural and historical situations. Ben-Rafael et al. (2006) believed that LL can not only mirror native primordial language settings, but demonstrate the relationship between political and societal power. In relation to case studies, 'LL research can thus help us to gain insight in aspects of linguistic diversity that typify the multilayered, super diverse multilingual contexts of late modern society, including aspects such as hybridity and multimodality, for instance.' (Garcia et al., 2017, p. 424). Moreover, Garcia even likens LL to 'an empirical barometer' (Garcia et al., 2017, p. 424) of human social activity because LL can assist us to observe both contemporary and historical transitions in language and society. Rosenbaum et al. (1977) also believed that LL can not only reflect the efficacy of local official language policy, but also demonstrate the popularity of other languages, such as English. Therefore, LL 'can be considered a major mechanism of language manipulation, as it determines not only the ideological message, but also the choice of languages' (Shohamy, 2006, p. 123).

\subsection{Language policy}

In light of the interpretation of sociolinguists, 'language policy (LP) is the primary mechanism for organizing, managing, and manipulating language behaviors as it consists of decisions made about languages and their uses in society. It is through LP that decisions are made concerning the preferred languages that should be legitimized, used, learned, and taught in terms of where, when and in which contexts' (Shohamy, 2006, p. 45). As a sort of linguistic activity at the political level, LP reflects on the reification of requisite language status in a speech community and influences daily communication in certain settings to maintain the social status of the target language.

According to the model coined by Spolsky (2004), language policy is split into three parts: language belief (ideology), language practice (ecology), and language management (planning). The first component is language belief, referring to the social ideology factor for the implementation of the LP. For instance, Singapore government is putting a particular emphasis on English, instead of Mandarin, to take care of the language habits of ethnic minorities such as Malays and Indians. There is a need to establish English as a unified national symbol for maintaining the equality of minorities. By comparison, language practice means that the target language should be used in specific settings. A typical example regarding the concept is the popularity of English around the globe. English is widely spread in various countries for more convenient international communication, which manifests the language practice. The last component is language management, referring to concrete actions that manipulate and determine language behavior under some contexts. (Shohamy, 2006). A common case for this term is that when Hong Kong people are aware of the inconvenience of Cantonese communication with Chinese people, they tend to speak Standard Mandarin rather than English as much as possible since English is not their common native language. Strictly speaking, when speakers with different native languages in one speech community exchange information, the speaker who masters hearers' mother tongue may use hearers' mother tongue to communicate as far as possible, instead of a second language they all are unfamiliar with. The discussion section includes the three branches of the LP for case analysis.

The other research pinpointed that the effectiveness of LP was given by Rosenbaum et al. (1977). In terms of the impact of LP on $\mathrm{LL}$, Rosenbaum and other scholars concluded that it has something to do with the contrast between the dominance of official language and the universal degree of a foreign language like English in the private sphere. More specifically, most LP across the world may not refrain from going to two types of extreme cases: driven by the authorities, the official language was widely spread in the public sphere, while the spread of non-official language still prevails in the private and commercial corporations due to real- 
life demand (Garcia et al., 2017). That is to say, the distinction between the official language and non-official language is a core interest in LL theories.

Therefore, scholars specially differentiated the LP into two types: the 'top-down' model and the 'bottom-up' model. The 'topdown' model means that language signs 'are expected to reflect a general commitment to the dominant culture'. In contrast, the 'bottom-up' model 'are designed much more freely according to individual strategies' (Ben-Rafael et al., 2006, p. 10). Normally, 'top-down' refers to language signs that are produced by the government, local councils, or the owner of a building or site. In contrast, 'bottom-up' refers to language signage that is made by individuals, the medium-sized and small business (Mooney \& Evans, 2015). The former serves for political power, and the latter infers that covert 'solidarity' (Backhaus, 2006). The above models would be mentioned for additional analysis in the result section.

Nevertheless, in recent years, the difference between 'top-down' and 'bottom-up' has begun to blur, because currently, 'the power of the state is often blended with the interests of the corporate.' (Luo, 2012, p. 46). This situation is not apparent in our research, so it would be ignored in the subsequent text.

The methodology of previous studies relies largely on quantitative data collection, involving interviews and observations. For example, Zhang (2016) used interviews conducted via phone, email, and in-person. Garvin (2010) collected photographic evidence by enlisting residents of Memphis to take photos of commercial signs on a designated street. Due to insufficient time to organize interviews, researchers relied on observational data collected using photography to investigate multilingual signs in public spaces. This case study would be explained fully in the methodology section.

\section{Methodology}

Photos of 46 landmarks were taken at Yangming Square and Gongbei Port on November 23, 2020. We collected the other 199 public signs at Fuhuali (Midtown) and Aoyuan Square on January 11 2021. To collect sufficient photographic evidence, we walked along every street and took pictures of most Chinese and English bilingual signs within the areas. The group split into two teams and went to the two areas on November 23. The first author was responsible for the Gongbei Port, including Weiji road, Qiaoguang road, and Shuiwan road. The correspondent author went to the Yangming shopping center, including Xianlie Road, Haiyan Road, and Cuihai Road. Afterward, the first author and the correspondent author photographed around 200 English signs at Midtown and Aoyuan Square in the afternoon on January 11.

To ensure the completeness of data, Baidu Maps and Auto Navi Map were used to obtain a bird's-eye view of the regions to identify any roads missed during our terrestrial investigation, with locally published books about Zhuhai's street names also referenced to complete the list. Finally, a list of the English names of these buildings and roads was collated by the researchers following the fieldwork.

Moreover, researchers looked through the information concerning multilingual policies on the official website of the Zhuhai government. The collected photos were categorized based on defined criteria, such as the presence of specific languages and categories of public facilities to which the signs were attached.

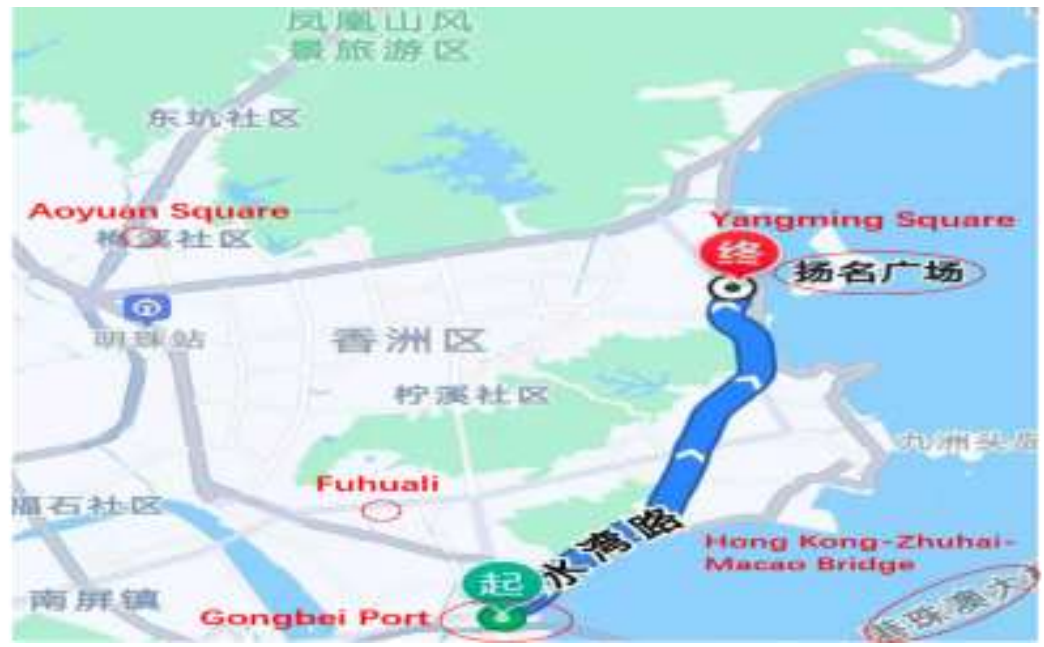

Figure 1. The map of Zhuhai city with the four areas. 


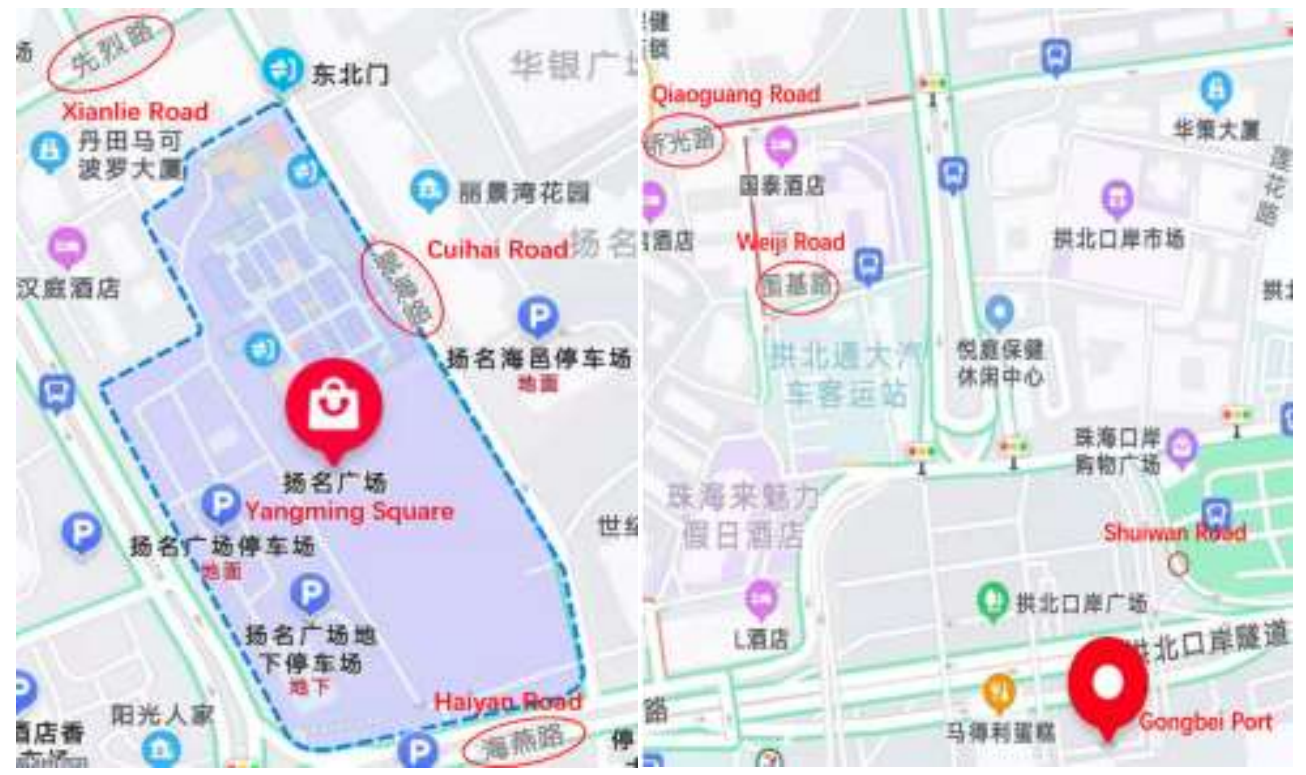

Figure 2. Yangming Square.

Figure 3. Gongbei Port.

\section{Findings}

Of the 245 public English signs investigated only 11 (4.49\%) were in Yangming Square as well as 35 (14.29\%) were in Gongbei Port, while most of the English signs are concentrated on the Midtown $(122,49.80 \%)$ and Aoyuan Square $(77,31.43 \%) .{ }^{1}$ The tables below involve the function of bilingual public signs in four regions. For convenience, the study results would be divided into two pairs to introduce: table 1 and table 2, table 3 and table 4 . The total bilingual signs are listed in the appendix.

Table 1. The Types of Shops of Chinese-English Bilingual Signs in Yangming Square $(n=11)$.

\begin{tabular}{cc}
\hline Types of Shops & Number (Proportion) \\
\hline Larceny Warning & $1(9.09 \%)$ \\
Public Facility & $1(9.09 \%)$ \\
Safety Warning & $7(63.64 \%)$ \\
Traffic Sign & $2(18.18 \%)$ \\
\hline Top-down & $11(100 \%)$ \\
Bottom-down & $0(0 \%)$ \\
\hline Total & 11 \\
\hline
\end{tabular}

Table 2. The Types of Shops of Chinese-English Bilingual Signs in Gongbei Port $(n=35)$.

\begin{tabular}{cc}
\hline Types of Shops & Number (Proportion) \\
\hline Coach Station & $2(5.71 \%)$ \\
Community Service & $1(2.86 \%)$ \\
Construction/Engineering Company & $3(8.57 \%)$ \\
Experience Service & $5(14.29 \%)$ \\
Hotel & $4(11.43 \%)$ \\
Larceny Warning & $1(2.86 \%)$ \\
Port Inspection & $2(5.71 \%)$ \\
Public Area Rule & $5(14.29 \%)$ \\
Retail/Shopping Mall & $1(2.86 \%)$ \\
Restaurant & $4(11.43 \%)$ \\
Tourist Agent Service & $4(11.43 \%)$ \\
Traffic Signs & $3(8.57 \%)$ \\
\hline Top-down & $10(28.57 \%)$ \\
Bottom-up & $25(71.43 \%)$ \\
\hline Total & 35 \\
\hline
\end{tabular}


Through comparative analysis it is evident that bilingual signs are more prevalent in Gongbei Port than in Yangming Square. As shown in Table 2, there was an even distribution of English signage between each type of public facility, with the largest number of English signs either attached to service providers or giving public area rules. As shown in Table 1, nearly half of all the English signs indicated safety warnings, but shops on the other hand did not have English language names. For example, to ensure the safety of the public, bilingual security notices regarding the moving walkway can be seen everywhere in Yangming Square; however, apart from official security signs, most shop owners appear disinterested in adopting an English name. The few that have used English language in their signage have used capital letters merely as a fashionable design feature to attract adolescent consumers' attention. By comparison, the English use in Gongbei Port is more practical, with both public places and commercial sites incorporating more professionally translated English on their signs. English is even used to address passengers in the lightrailway station. Moreover, the surrounding roads of Gongbei Port house plenty of shops with bilingual titles. These store owners take the view that "Chinese and English used together can make it easy for Chinese and foreign readers to understand the shop name and at the same time make the shop name more sound a bit 'international'" (Guo \& Li, 2017, p. 5). Based on this evidence, researchers conclude that Gongbei Port has a higher international service standard and denser multilingual atmosphere than Yangming Square.

Furthermore, almost all English signs in Yangming Square belong to the 'top-down', while most English signs in Gongbei Port are concentrated on the 'bottom-up'. Researchers deduced from this phenomenon that Gongbei Port involves more bilingual signs from the commercial organization and private places. By comparison, as a typical commercial area, the development of English signs in the Yangming square is almost entirely provided by local councils and shops.

Table 3. The Types of Shops of Chinese-English Bilingual Signs in Fuhuali (Midtown) $(n=122)$.

\begin{tabular}{cc}
\hline Types of Shops & Number (Proportion) \\
Art/Life/Gift & $3(2.46 \%)$ \\
Bank \& Service & $1(0.82 \%)$ \\
Children's Service & $7(5.74 \%)$ \\
Entertainment & $9(7.38 \%)$ \\
Food/Beverage/Coffee Store & $12(9.84 \%)$ \\
Health/Beauty & $5(4.10 \%)$ \\
& $1(0.82 \%)$ \\
Hotel & $2(1.64 \%)$ \\
Idiom Slogan & $39(31.97 \%)$ \\
Ladies' Fashion Store & $17(13.93 \%)$ \\
Men's Fashion Store & $3(2.46 \%)$ \\
Shoe/Bag & $7(5.74 \%)$ \\
Square Name & $9(7.38 \%)$ \\
Street Name & $7(5.74 \%)$ \\
\hline Watches/Jewelry/Accessory & $7(5.74 \%)$ \\
Top-down & $115(94.26 \%)$ \\
\hline
\end{tabular}

Table 4. The Types of Shops of Chinese-English Bilingual Signs in Aoyuan Square $(n=77)$.

\begin{tabular}{cc}
\hline Types of Shops & Number (Proportion) \\
\hline Clothes Shop & $7(9.09 \%)$ \\
Daily Necessities & $14(18.18 \%)$ \\
Experience Service & $2(2.60 \%)$ \\
Food/Beverages/Coffee Sign & $16(20.78 \%)$ \\
Ladies' Fashion Store & $2(2.60 \%)$ \\
Men's Fashion Store & $2(2.60 \%)$ \\
Public Facility & $12(15.58 \%)$ \\
Safety Warning & $20(25.97 \%)$ \\
Watch/Jewelry/Accessory & $2(2.60 \%)$ \\
\hline Top-down & $32(41.56 \%)$ \\
Bottom-up & $45(58.44 \%)$ \\
\hline Total & 77
\end{tabular}


In terms of the distinction in number, Midtown involves more bilingual signs than Aoyuan Square. As illustrated in Table 3, almost half of English signs (45.7\%) are English translations of fashion store names. To be more specific, the percentage of ladies' fashion store is the highest, $31.97 \%$, which is close to one-third of the total number of English signs, compared to $0.82 \%$ that of bank $\&$ service and hotel regarded as the lowest of them. Children's service, entertainment, square name, street name, and watches/jewelry/accessory are quite similar, and their percentages are around 8\% approximately. By contrast, art/life/gift and shoe/bag share the same proportion: $2.46 \%$.

Meanwhile, food/beverage/coffee store and health/beauty account for $9.84 \%$ and $4.1 \%$, respectively. Besides, Midtown is the opposite of Yangming Square: the vast bulk of English signs belong to the 'bottom-up'. More importantly, though most shop owners in Midtown are also not keen on adopting an English name, import brands' attribute determines that these fashion shops need formal English names to draw adolescents' attention.

When it comes to Aoyuan Square, local personnel focus less on English signs than the Midtown as mentioned earlier. Safety warning topped the list with a figure of $25.97 \%$. Next came to food/beverages/coffee sign, whose proportion accounts for $20.78 \%$. The data for other categories are considerably lower, and clothes shops only have $9.09 \%$, half of the daily necessities (18.18\%). Comparing with that, the ratio for experience service, watch/jewelry/accessory, ladies' fashion store, and men's fashion store are quite closed, maintaining approximately $2.6 \%$.

Moreover, the number of English signs in Aoyuan Square is almost evenly distributed into the top-down and bottom-up models. The categories of the top-down model mainly cover public facilities and safety warnings. As shown in the below two pictures, 20 safety warning signs and two public facilitate signs concerning fire protection all appear in one same area. The English translation of these warning signs is practical indeed. However, the fire safety management system (the left side of the right picture) that is more important has not been translated into English sentence by sentence, which is an obvious working inadvertence.
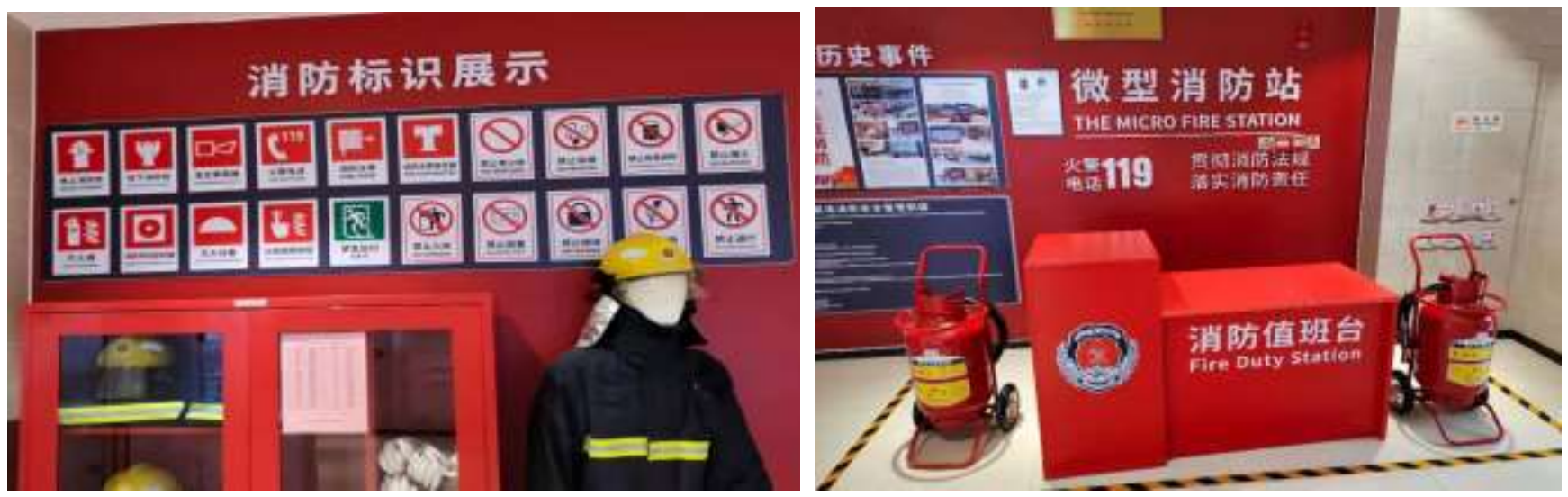

Figure 4. The Fire Safety Management System of Aoyuan Square.

\section{Additional finding}

The below chart involves several interesting translation examples:

\begin{tabular}{|c|c|c|c|c|c|}
\hline English & Mandarin & Function & English & Mandarin & Function \\
\hline It's worth it & 人间值得* & Idiom Slogan & N2 Dance Studio & 扭兔舞蹈培训 & $\begin{array}{l}\text { Experience } \\
\text { Service }\end{array}$ \\
\hline $\begin{array}{l}\text { The future is } \\
\text { promising }\end{array}$ & 未来可期* & Idiom Slogan & Lukfook & 六福珠宝 & $\begin{array}{l}\text { Watch/ } \\
\text { Jewelry/ } \\
\text { Accessory }\end{array}$ \\
\hline Champion Pizza & $\begin{array}{c}\text { 尊宝比萨* } \\
\text { (Zunbao Pizza) }\end{array}$ & Food Store & Chow Tai Fook & 周大福 & $\begin{array}{l}\text { Watches/ } \\
\text { Jewelry/ } \\
\text { Accessory }\end{array}$ \\
\hline Gossen & 九芯 & Daily Necessities & $\begin{array}{l}\text { Canton Classic } \\
\text { Chicken Hot Pot }\end{array}$ & 广州芳村榕树头* & Traffic Sign \\
\hline $\begin{array}{c}\text { Tupperware } \\
\text { Danker }\end{array}$ & $\begin{array}{l}\text { 特百惠 } \\
\text { 蛋壳披萨 }\end{array}$ & $\begin{array}{l}\text { Daily Necessities } \\
\text { Food Store Sign }\end{array}$ & Keyroad & 启路 & Clothes Shop \\
\hline
\end{tabular}

*Four public signs are free translation. 
Homophonic translation and free translation with implied meaning are the main methods to realize the practical value of brandname translation. Of the above 11 business shop names, only 4 are free translation, and the other 7 are transliteration. Gossen (gau2 sam 1), Lukfook (luk6 fuk1), and Chow Tai Fook (zau1 taai3 fuk 1) ${ }^{3}$, the three celebrated commercial brands from Hong Kong, are typical Cantonese homophonic translation.

In the following free translation examples, their Chinese shop names' English translations do not completely profess their intended meaning. Firstly, the original Chinese meaning of 'it's worth it' is 'finding the world worthwhile.' Secondly, the 'champion', actually, this word does not exist in the Chinese shop name, 'zunbao Pizza.'4 The direct translation of 'zunbao' is 'the noble baby'. Nonetheless, 'champion', this word can better express parents' eagerness for their children's growth than 'zunbao'. Thirdly, the 'Canton Classic Chicken Hot Pot', to a certain extent, it's easier for the English translation of this shop name than that of Chinese name to understand. The shop name originally means that Canton's fragrant village and the banian tree. Interestingly, Chinese consumers may not know what cuisine this shop serves if there is no English translation.

\section{Discussion}

This study aims to provide a holistic description of the use of English language signage in Zhuhai's public spaces. Although our limited data from only four areas is insufficient to represent all of Zhuhai, our findings are almost consistent with that of a previous study, which stated that 'The distinct social status of the different languages leads to different functions and powers' (Zhang, 2016, p. 599).

\subsection{The significance of the research (factors affecting the public use of English)}

Specifically, the sociocultural situation and variety of target audiences have an important impact on the distribution of bilingual signs. This conclusion can be observed in relation to the current distribution of English speakers in Zhuhai. Gongbei Port is close to Macau and the Hong Kong-Zhuhai-Macao Bridge, resulting in a regular influx of foreign tourists who require English signage, leading to the increased application of English in this location. Conversely, the remote suburbs of Zhuhai mainly house local people, meaning entertainment centers such as Yangming Square do not need to focus on the implementation of multilingual signage. Midtown is situated in the nearby Gongbei Port regions, so the bilingual coverage of Midtown is evidently more extensive than Aoyuan Square. Most private enterprises utilize English names to catch young consumers' attention and create an attractive atmosphere with foreign cultural elements (Zhang, 2016). This cause suggests that the target audience is the greatest factor in the implementation of English signage.

In addition, the function of facilities makes a difference to the degree of English used. Administrative departments and transportation hubs generally have relatively professional English translations, while the English names of some businesses are incomplete and in nonstandard English. For example, 'Zhuhai General Station of Exit and Entry Frontier Inspection of the People's Republic of China' conveys the purpose of this particular office; however, the incomplete, literal translation 'Huiyu Business' does not give English speakers the information that it is a commercial intermediary organization. The two causes of the phenomena include: first and foremost, the government deserves to ensure foreigners recognize specific government departments, to provide convenience for them to handle passport, international investment treatment, and other affairs; secondly, the local main passenger flow is Chinese citizens, unnecessary to design professional translation for a small number of foreign consumers. Thus, these incomplete translations are more decorative than practical meaning.

\subsection{The implication for the government (solutions to problems)}

In addition to nonstandard English translation, the Zhuhai government does not focus on the perfection of foreign language service. In light of the official website of the Zhuhai government, Article VIII of Interim Provisions on the Release of Food Advertisement: 'Foreign languages shall not be used alone in advertisements. If foreign languages are used in advertisements due to special needs, standard Mandarin (Putonghua) and standard Chinese characters shall be used as the main form, supplemented by foreign languages. If the meaning expressed by the foreign language in the advertisement is inconsistent with the Chinese meaning, the Chinese meaning shall prevail.' Thus it can be seen, maintaining the dominance of Mandarin is the language ideology of the Zhuhai government. Though there is a demand to attract foreign investment, English has still not altered its supplementary language status in Zhuhai. In terms of language practice, the government's popularization of standard Mandarin has also marginalized the construction of foreign language services. For language management, such advertising regulations will curb the frequency of foreign languages in advertising. This policy will be detrimental to the development of foreign languages in China, including English.

By addressing these issues, the municipal government may invite linguists to participate in the policy planning of international language services and set up professional organizations to implement relevant policies, such as the Zhuhai Language Working 
Committee and the Zhuhai International Language Institute. More importantly, the Zhuhai Bureau of Education may encourage varied pedagogic techniques to enhance the effect of English linguistic acquisition on students. Related departments ought to facilitate college-enterprise collaboration to attract more bilingual talents.

\section{Conclusion}

In conclusion, Gongbei Port and its vicinity have a high degree of practical English signage in relation to other recreational areas of Zhuhai. Most English signage in Midtown and Aoyuan Square are fashion shop English names. A target audience of tourists and the diverse provision of facilities are two influential factors in the development of Zhuhai English signage. To be more specific, the large proportion of adolescents determines multitudes of shops need English signage to attract young consumers' attention. Furthermore, places next to Gongbei port must provide necessary English signage for foreigners who come from Hong Kong and Macao. It can help foreigners overcome language barrier and provide more living convenience.

However, there is a gap in the coverage rate of Chinese-English bilingual signs of public facilities in Zhuhai, which does not achieve omnidirectional coverage. The government needs a high standard of English language accuracy to give foreigners a good impression and a quaint 'Chinglish' to amuse tourists and signal cultural hybridity. To put it differently, the existence of 'Chinglish' signage combines the linguistic characteristics from Chinese and English, which may effectively increase the cultural diversity and interest (See additional finding). In addition, to improve the local quality of language services, the Zhuhai municipal consultant team is currently crying out for more bilingual talent, such as linguists and translators. These issues call for continuous action from the government.

However, the study has some limitations that have not been overcome. Firstly, the research scope of the study merely covers four main areas, which does not necessarily represent the whole Zhuhai's language cultural landscape. Secondly, this study is high in internal validity but low in external validity, as all of research materials from Zhuhai. Chances are that the findings cannot be generalized to other quite different background. According to our theoretical research, subsequent linguists and educators may consider similar drawbacks and focus on what they need to ameliorate in their further research. If this is the case, we welcome more relevant researchers to give precious suggestion to our study.

\section{Acknowledgements}

We would like to appreciate our supervisor, professor John Corbett for his assistance and enthusiasm to the research.

\section{Notes}

1. Generally speaking, bilingual public signs in mainland China usually bear Chinese names above the English translation, and the size of the former is much larger than the latter. This is a crucial indicator of the dominance of the official language (Lai, 2013).

2. Experience Service mainly includes: fitness club, KTV, SPA, nightclub, footbath store, etc.

3. Chow Tai Fook is the largest listed jewelry company in Hong Kong. Chow is a common surname in China; Tai Fook refers to good fortune or luck. Lukfook is one of the major jewelry retailers in Hong Kong and mainland China. Luk refers to six (In China, six is a lucky number that symbols wealth).

4. In the Chinese language, 'zunbao' implies that parents want their children are able to make something of their future career.

\section{Disclosure statement}

No potential conflict of interest was reported by the author.

\section{References}

[1] Amos, H. W. (2015). Redefining Multilingual Signs in the Linguistic Landscape: Discursive Content and Test-Types on Street Signs in Toulouse. International Journal of Mulingualism.

[2] Backhaus, P. (2006). "Mulingualism in Tokyo: A Look into the Linguistic Landscape." International Journal of Multilingualism 3(1), 52-66.

[3] Backhaus, P. (2007). Linguistic Landscape: A Comparative Study of Urban Mulingualism in Tokyo. Clevedon, UK:Multilingual Matters.

[4] Backhaus, P. (2009). "Rule and Regulations in Linguistic Landscape: A Comparative Perspective." In E. Shohamy and D. Gorter (eds.), Linguistic Landscape: Exapnding the Scenery (pp.157-172). London: Routledge.

[5] Ben-Rafacl, Eliczer, Elana Shohamy, Muhammad Hasan Amara, and Nira Trumper-Hccht. (2006). "Linguistic Landscape as Symbolic Construction of the Public Space: The Case of Israel." International Journal of Mulilingualism 3(1), 7-30.

[6] Block, D. (2014). Social Class in Applied Linguistics. London: Routledge.

[7] Blommaert, J. (2010). The Sociolinguistics of Globalization. Cambridge: Cambridge University Press.

[8] Blommaert, J., \& B. Rampton. (2011). "Language and Superdiversity". Diversity 13 (2), 1-21.

[9] Bolton, K. (2012). World Englishes and Linguistic Landscapes. World Englishes. 31 (1), 30-33.

[10] Coupland, N. (2012). "Bilingualism on Display: The Framing of Welsh and English in Welsh Public Spaces." Language in Society 41 (1), $1-27$.

[11] Eco, U. (1988). Le Signe. Brussels: Editions Labor.

[12] Garcia, O., Flores, N., \& Sptti, M. (2017). The Oxford Handbook of language and society (5 ${ }^{\text {th }}$ ed., pp. 423-450). Oxford: Oxford University Press. 
[13] Gravin, R. T. (2010). Responses to the Linguistic Landscape in Memphis, Tennessee: An Urban Space in Transition. In E. Shohamy, E. BenRafael, \&M. Barni (Eds.), Linguistic Landscape in the City (pp. 252-271). Bristol: Multilingual Matters.

[14] Gorter, D. (2013). "Linguistic Landscapes in a Multilingual World." Annual Review of Applied Linguistics 33,190-212.

[15] Guo, G. H., \& Li, B. J. (2017). Linguistic Landscape of China: A Case Study of the Language Use of Shop Sign in Wuhan. Studies in Literature and Language, 15(1), 1-9. http://dx.doi.org/10.3968/9816

[16] Heller, M. (2011). Paths to Post-Nationalism: A Critical Ethnography of Language and Identity. Oxford: Oxford University Press.

[17] Helot, C., M. Barni, R. Janssens, and C. Bagna. (eds.). (2012). Linguistic Lnadscape, Multilingualism and Social Change. Frankfurt am Main: Peter Lang.

[18] Jarlched, Johan. (2017). "Methdology in Linguistic Landscape Research." Linguistic Landscape: An International Journal 3(3), $286-305$.

[19] Jaworiski, A., \& C. Thurlow. (eds.). (2010). Semiotic Landscapes: Language, Image, Space. London: Continuum.

[20] Lai, M. L. (2013). "The Linguistic Landscape of Hong Kong After the Change of Sovereignty." International Journal of Multilingualism 10 (3), $251-272$.

[21] Landry, R., \& R. Y. Bourhis. (1997). "Linguistic Landscape and Ethnolinguistic Vitality An Empiricial Study". Journal of Language and Social Psychology. 16 (1), 23-49.

[22] Luo, J. J. (2012). "Chinatown in Washington, DC: The Bilingual Landscape." World Englishes 31(1), 34-47.

[23] Mooney, A, \& Evans, B. (2015). Language, Society and Power (4 ${ }^{\text {th }}$ edition). London and New York: Routledge, pp.86-107

[24] Peck, A., \& C. Stroud. (2015). "Skinscapes." Linguistic Landscape: An International Journal 1(1-2),133-151.

[25] Raos, V. (2018). Bilinugal street sign policy in EU member states: a comparison. Journal Of Multilingualism And Multicultural Development, 39 (10), 895-911.

[26] Rosenbaum, Y., E. Nadel, R. L. Cooper, \& J.A. Fishman. (1977). "English on Keren Kayement Street." In J. A. Fishman, R. L. Cooper and A. W. Conrad (eds.), The Spread of English (pp.179-196). Rowlev. MA: Newbury House.

[27] Shohamy, E. (2006). Language Policy: Hidden agendas and new approaches ( $1^{\text {st }}$ ed., pp.110-113). New York: Routledge.

[28] Shang, G., \& Zhao, S. (2014). Perspectives, Theories and Methods of Linguistic Landscape Research. CNKI: SUN: WJYY.0.2014-02-226.

[29] Spolsky, B., \& R. L. Cooper. (1991). The Languauges of Jerusalem. Oxford: Clarendon Press.

[30] Song, G. (2019). Conflicts and complexities: A study of Hong Kong's bilingual street signs from functional perspective on translation. Journal of Multilingual and Multicultural Development, 41(10), 886-898. https://doi.org/10.1080/01434632.2019.1663860

[31] Zhang, H. (2016). Plurilingual posters in a multilingual city: reader positioning and power negotiation. Language and Intercultural Communication, 16(4), 588-609.

[32] Zhuhai renmin shizhengfu menhu wangzhan [Portal website of Zhuhai People's Government (n.d.)]. Retrieved January 16, 2021 from http://www.zhuhai.gov.cn.

\section{Appendix}

Table 1. Yangming Square $(n=11)$.

\begin{tabular}{|c|c|c|c|c|c|}
\hline English & Mandarin & Function & English & Mandarin & Function \\
\hline $\begin{array}{c}\text { Internal } \\
\text { Monitoring, } \\
\text { please smile }\end{array}$ & 内有监控, 请您微笑 & Larceny Warning & Hold the handrail & 握住扶手带 & Safety Warning \\
\hline WC & 公共则所 & Public Facility & Hold your pet & 宠物必须抱着 & Safety Warning \\
\hline $\begin{array}{l}\text { Don't play } \\
\text { water }\end{array}$ & 请勿嬉水 & Safety Warning & Mind your head & 小心碰头 & Safety Warning \\
\hline $\begin{array}{l}\text { Watch your } \\
\text { step }\end{array}$ & 小心台阶 & Safety Warning & Xianlie Road & 先烈路 & Traffic Sign \\
\hline $\begin{array}{l}\text { No stroller } \\
\text { Hold on to } \\
\text { your child }\end{array}$ & $\begin{array}{c}\text { 禁止使用手推车 } \\
\text { 小孩必须拉住 }\end{array}$ & $\begin{array}{l}\text { Safety Warning } \\
\text { Safety Warning }\end{array}$ & Cuihai Road & 翠海路 & Traffic Sign \\
\hline
\end{tabular}

Table 2. Gongbei Port $(n=35)$.

\begin{tabular}{|c|c|c|c|c|c|}
\hline English & Mandarin & Function & English & Mandarin & Function \\
\hline $\begin{array}{l}\text { Gongbei Tongda } \\
\text { Coach Station }\end{array}$ & $\begin{array}{c}\text { 拱北通大汽车客运 } \\
\text { 站 }\end{array}$ & Coach Station & $\begin{array}{l}\text { Zhuhai General Station of } \\
\text { Exit and Entry Frontier } \\
\text { Inspection of the People's } \\
\text { Republic of China }\end{array}$ & $\begin{array}{c}\text { 中华人民共和国 } \\
\text { 珠海出入境边防 } \\
\text { 检查总站 }\end{array}$ & Port Inspection \\
\hline $\begin{array}{l}\text { Ticket Hall Waiting } \\
\text { Room }\end{array}$ & 售票候车大厅 & Coach Station & $\begin{array}{c}\text { Zhuhai International Travel } \\
\text { Healthcare Center }\end{array}$ & $\begin{array}{c}\text { 珠海国际旅行卫 } \\
\text { 生保健中心 }\end{array}$ & Port Inspection \\
\hline $\begin{array}{c}\text { Ying Bin } \\
\text { Community } \\
\text { Service Center }\end{array}$ & $\begin{array}{c}\text { 迎宾社区党群服务 } \\
\text { 中心 }\end{array}$ & Community Service & No cycling & 禁止自行车入内 & Public Area Rule \\
\hline $\begin{array}{l}\text { China State } \\
\text { Construction }\end{array}$ & 中国建业 & Engineering Company & No Photographing & 禁止拍照 & Public Area Rule \\
\hline $\begin{array}{l}\text { We are open } \\
\text { during renovation, }\end{array}$ & $\begin{array}{c}\text { 装修升级, 酒店正 } \\
\text { 常营业, 请移步至 } \\
\text { 侧门通往大堂。 }\end{array}$ & Engineering Company & No Pets Allowed & 禁止宠物入内 & Public Area Rule \\
\hline
\end{tabular}


please proceed the side entrances

Wang Ngai AirCondition

Engineering Co. LTD

Charming Female Dept. Store

来魅力女人世界 Experience Service

\begin{tabular}{|c|c|c|}
\hline La Golden Era & 流金岁月 & Experience Service \\
\hline $\begin{array}{l}\text { Professional hot } \\
\text { dyeing shop }\end{array}$ & 专业洗发店 & Experience Service \\
\hline $\begin{array}{l}\text { SPA, Foot \&Body } \\
\text { Massage }\end{array}$ & $\begin{array}{l}\text { SPA，足浴, 中泰式 } \\
\text { 按摩 }\end{array}$ & Experience Service \\
\hline $\begin{array}{c}\text { Aroma, Oil } \\
\text { Treatment } \\
\text { Specialist }\end{array}$ & $\begin{array}{c}\text { 香薰推拿, 专家理 } \\
\text { 疗 }\end{array}$ & Experience Service \\
\hline $\begin{array}{c}\text { Charming Holiday } \\
\text { Hotel }\end{array}$ & 来美丽假日酒店 & Hotel \\
\hline Friendship Hotel & 友谊酒店 & Hotel \\
\hline $\begin{array}{l}\text { Xin Hao Run } \\
\text { Holiday Hotel }\end{array}$ & 新濠润假日酒店 & Hotel \\
\hline $\begin{array}{c}\text { Golden Fortune } \\
\text { Hotel }\end{array}$ & 金海景裕酒店 & Hotel \\
\hline $\begin{array}{c}\text { The mall on video } \\
\text { analysis }\end{array}$ & $\begin{array}{c}\text { 本商场监控录像在 } \\
\text { 启用中 }\end{array}$ & Larceny Warning \\
\hline $\begin{array}{l}\text { Japanese BBQ \& } \\
\text { Craft Beer }\end{array}$ & 龙涯烧 & Restaurant \\
\hline Koo Chun Tong & 古春堂凉茶 & Restaurant \\
\hline
\end{tabular}

No Smoking

Construction

公司

Company

Restaurant

\section{The use of carts and trolleys are strictly prohibited except those that comply with Port \\ Plaza standards \\ Zhuhai Port Plaza \\ TaiSamBa \\ Colorfulness}

Huiyu Business

Tourist Distribution Center

Zhuhai Red Sun International Tourist Agent Service

Gongbei Port

Zhuhai Railway Station

Banzhangshan Tunnel

Meng Fei Yang Buffet Restaurant
禁止非广场统一 标准的平板车入

内

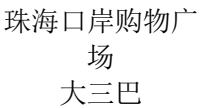

缤纷国际旅行社

慧雨商务

旅游集散中心

珠海市红阳国际 旅行社

拱北口岸

珠海站

板樟山隧道

蒙肥羊(fatten calf)自助餐厅
Public Area Rule

Shopping Mall

Restaurant

Tourist Agent Service

Tourist Agent Service

Tourist Agent Service

Tourist Agent Service

Traffic Sign

Traffic Sign

Traffic Sign

Restaurant

Table 3. Fuhuali (Midtown) $(n=122)$.

\begin{tabular}{|c|c|c|c|c|c|}
\hline English & Mandarin & Function & English & Mandarin & Function \\
\hline HUAWEI & 华为 & Gift & MISS SIXTY & & Ladies' Fashion Store \\
\hline MI & 小米 & Gift & ACUPUNCTURE & & Ladies' Fashion Store \\
\hline HIMO & 海马 & Gift & ochirly & 欧时力 & Ladies' Fashion Store \\
\hline Villa Art School & & Educational Service & Donoratico & 达衣岩 & Ladies' Fashion Store \\
\hline URBAN REVIVO & & Children's Service & VANS & & Ladies' Fashion Store \\
\hline$H \& M$ & & Children's Service & eifini & 伊芙丽 & Ladies' Fashion Store \\
\hline ROOKIE & & Children's Service & TITI & & Ladies' Fashion Store \\
\hline BB KINGDOM & & Children's Service & HEA & & Ladies' Fashion Store \\
\hline LEGO & 乐嘉 & Children's Service & JESSY LINE & 杰茜莱 & Ladies' Fashion Store \\
\hline HEA & & Children's Service & MO\&CO. & & Ladies' Fashion Store \\
\hline MELAND & 反斗乐园 & Children's Service & VERO MODA & & Ladies' Fashion Store \\
\hline TSINGTAO1903 & 青岛啤酒 & Entertainment & SUPIN & 速品 & Ladies' Fashion Store \\
\hline AZUR BAR & 中蓝海 & Entertainment & Suidoubasi & 水道桥 & Ladies' Fashion Store \\
\hline LUCKY HOUSE BAR & 幸运酒窝 & Entertainment & MEILLEUR MOMENT & 蒙檬 & Ladies' Fashion Store \\
\hline A CLUB & 酒吧 & Entertainment & BAISI & & Ladies' Fashion Store \\
\hline
\end{tabular}




\begin{tabular}{|c|c|c|c|c|c|}
\hline BANANA & 香蕉放题 & Entertainment & Adidas mega L2 & 阿迪达斯 & Ladies' Fashion Store \\
\hline GTWO KTV & & Entertainment & SEA HORSE & 海马潮牌品汇 & Ladies' Fashion Store \\
\hline Orange Club & 发条橙子酒吧 & Entertainment & NIKE & 耐克 & Ladies' Fashion Store \\
\hline JUNGLE CAFÉ \& PUB & 蘑菇吧 & Entertainment & Adidas NEO & & Ladies' Fashion Store \\
\hline Emperor UA Cinema & 英皇 UA 电影院 & Entertainment & AQEACARMON & & Men's Fashion Store \\
\hline THREE DROPS & 参色 & Beverage Store & URBAN REVIVO & & Men's Fashion Store \\
\hline Starbucks & 星巴克 & Coffee Store & J. LINDEBERG & & Men's Fashion Store \\
\hline WANG STEAK & 王品牛排 & Food Store & SELECTED & & Men's Fashion Store \\
\hline Refill & $\begin{array}{c}\text { 悦府中国意境菜 } \\
\text { 餐吧 }\end{array}$ & Food Store & SEA HORSE & & Men's Fashion Store \\
\hline A SHOP & 餐吧 & Food Store & $\mathrm{H} \& \mathrm{M}$ & & Men's Fashion Store \\
\hline SUBWAY & 赛百味 & Food Store & ACUPUNCTURE & & Men's Fashion Store \\
\hline O-POKE & & $\begin{array}{c}\text { Food/Beverage/ } \\
\text { Coffee Store }\end{array}$ & JACK\&JONES & & Men's Fashion Store \\
\hline PizzaHut & 必胜客 & Food Store & VANS & & Men's Fashion Store \\
\hline COMEBUY & 甘杯 & Beverage Store & HEA & & Men's Fashion Store \\
\hline SEVEN BUS & & Beverage Store & MR. COLLECTION & & Men's Fashion Store \\
\hline CHEERSCHEESE & 干杯起司 & Food/Beverage Store & POLO SPORT & & Men's Fashion Store \\
\hline Pacific Coffee & 太平洋咖啡 & Coffee Store & Adidas mega L2 & 阿迪达斯 & Men's Fashion Store \\
\hline Watsons & 屈臣氏 & Beauty & Adidas NEO & & Men's Fashion Store \\
\hline Beauty star & 美丽星辰 & Beauty & SEA HORSE & 海马 & Men's Fashion Store \\
\hline THE COLORIST & 调色师 & Beauty & FILA & & Men's Fashion Store \\
\hline HM by Hair Code & 芭曲发型机构 & Beauty & OMI & 欧米 & Shoe / Bag \\
\hline MYFACE & 美颜坊 & Beauty & Samsonite & 新秀丽 & Shoe/Bag \\
\hline Pullman House & 铂尔曼酒店 & Hotel & OnitsuKa Tiger & 鬼冢虎 & Shoe/Bag \\
\hline $\begin{array}{l}\text { The future is } \\
\text { promising }\end{array}$ & 未来可期 & Idiom Slogan & Northwest Square & 西北广场 & Square Name \\
\hline It's worth it & 人间值得 & Idiom Slogan & Water tower Square & 水塔广场 & Square Name \\
\hline DAZZLE & & Ladies' Fashion Store & Wishing Sqaure & 心愿广场 & Square Name \\
\hline $\mathrm{d}^{\prime} z z i t$ & & Ladies' Fashion Store & South Square & 南广场 & Square Name \\
\hline FILA & & Ladies' Fashion Store & Southeast Square & 东南广场 & Square Name \\
\hline AQEACARMON & & Ladies' Fashion Store & Central Square & 中央广场 & Square Name \\
\hline Conatus & & Ladies' Fashion Store & Holiday Square & 假日广场 & Square Name \\
\hline MASELEY & 玛塞莉 & Ladies' Fashion Store & South Street & 南街 & Street Name \\
\hline LAURELINE & 洛瑞琳 & Ladies' Fashion Store & Dear Street & 鹿街 & Street Name \\
\hline EXCEPTION & 例外 & Ladies' Fashion Store & Ox Street & 牛街 & Street Name \\
\hline esons & & Ladies' Fashion Store & Elephant Street & 象街 & Street Name \\
\hline IIIVIVINIKO & 薇薏冦 & Ladies' Fashion Store & Bird Street & 雀街 & Street Name \\
\hline
\end{tabular}




\begin{tabular}{|c|c|c|c|c|c|}
\hline URBAN REVIVO & & Ladies' Fashion Store & Horse Street & 马街 & Street Name \\
\hline YMOYNOT & & Ladies' Fashion Store & North Street & 北街 & Street Name \\
\hline Marisfrolg. SU & 玛丝菲尔素 & Ladies' Fashion Store & Baihe (lily) Street & 百合街 & Street Name \\
\hline broadcast & 播 & Ladies' Fashion Store & Fuhua East Street & 富华东街 & Street Name \\
\hline fandecie & 芬狄诗 & Ladies' Fashion Store & HITOMMI & 希多蜜 & $\begin{array}{c}\text { Watch/Jewelry/ } \\
\text { Accessory }\end{array}$ \\
\hline EVE'S TEMPTATION & 夏娃的诱惑 & Ladies' Fashion Store & IN MIX & 音米 & $\begin{array}{c}\text { Watch/Jewelry/ } \\
\text { Accessory }\end{array}$ \\
\hline ONLY & & Ladies' Fashion Store & ARtinna\&Co. & & $\begin{array}{c}\text { Watch/Jewelry/ } \\
\text { Accessory }\end{array}$ \\
\hline SEA HORSE & 海马 & Ladies' Fashion Store & CASIO & 卡西欧 & $\begin{array}{c}\text { Watch/Jewelry/ } \\
\text { Accessory }\end{array}$ \\
\hline$H \& M$ & & Ladies' Fashion Store & REESE & 瑞茜 & $\begin{array}{c}\text { Watch/Jewelry/ } \\
\text { Accessory }\end{array}$ \\
\hline Edition & & Ladies' Fashion Store & EGG & & $\begin{array}{c}\text { Watch/Jewelry/ } \\
\text { Accessory }\end{array}$ \\
\hline Initial & & Ladies' Fashion Store & SHINE & 萱子饰品 & Accessory \\
\hline
\end{tabular}

Table 4. Aoyuan Square $(n=77)$.

\begin{tabular}{|c|c|c|c|c|c|}
\hline English & Mandarin & Function & English & Mandarin & Function \\
\hline Gold lion & & Clothes Shop & Change She & & Ladies' Fashion Store \\
\hline Key road & 启路 & Clothes Shop & Only & & Ladies' Fashion Store \\
\hline My body & & Clothes Shop & Anta & & Men's Fashion Store \\
\hline Balabala & & Clothes Shop & Septwolves & 七匹狼 & Men's Fashion Store \\
\hline Ochirly & & Clothes Shop & Service Counter & 服务台 & Public Facility \\
\hline Donoratico & & Clothes Shop & Self Service Express & 自助付款快线 & Public Facility \\
\hline URBAN REVIVO & & Clothes Shop & $\begin{array}{l}\text { Integrated payment } \\
\text { channel }\end{array}$ & 综合支付通道 & Public Facility \\
\hline Baking tools & 烘培器具 & Daily Necessities & Food Balcony & 美食露台 & Public Facility \\
\hline Baking ingredients & 烘培辅料 & Daily Necessities & Wonder Forest & 华夏世嘉 & Public Facility \\
\hline Preservation bag & 保鲜袋 & Daily Necessities & My Gym & 美吉姆 & Public Facility \\
\hline $\begin{array}{l}\text { Disposable } \\
\text { supplies }\end{array}$ & 一次性用品 & Daily Necessities & Century Star Bank & 世纪星滑冰场 & Public Facility \\
\hline Oil pollution & 去油污 & Daily Necessities & Public Square & 市民广场 & Public Facility \\
\hline Kitchen piece & 厨房小件 & Daily Necessities & Cashier & 收银台 & Public Facility \\
\hline Leather Care & 皮革护理 & Daily Necessities & Escalator & 扶梯 & Public Facility \\
\hline Kitchen Tissue & 㕌房用纸 & Daily Necessities & $\begin{array}{l}\text { The micro fire } \\
\text { station }\end{array}$ & 微型消防站 & Public Facility \\
\hline $\begin{array}{l}\text { Disposable } \\
\text { Tableware }\end{array}$ & 一次性餐具 & Daily Necessities & Fire duty station & 消防值班台 & Public Facility \\
\hline Tidal Supplies & 防潮用品 & Daily Necessities & Round Hydrant & 地上消防栓 & Safety Warning \\
\hline Garbage bags & 垃圾袋 & Daily Necessities & $\begin{array}{c}\text { Underground } \\
\text { Hydrant }\end{array}$ & 地下消防栓 & Safety Warning \\
\hline Pet & 宠物 & Daily Necessities & $\begin{array}{c}\text { Sound warning } \\
\text { device }\end{array}$ & 发生报警器 & Safety Warning \\
\hline
\end{tabular}




\begin{tabular}{|c|c|c|c|c|c|}
\hline $\begin{array}{l}\text { Toilet cleaning } \\
\text { articles }\end{array}$ & 洁则用品 & Daily Necessities & Fire telephone & 火警电话 & Safety Warning \\
\hline Razor & 剃须刀 & Daily Necessities & Fire hose & 消防水带 & Safety Warning \\
\hline HAIR \& LOGY & 丝域养发 & Experience Service & Fire pump adapter & 消防水原接合器 & Safety Warning \\
\hline $\begin{array}{c}\text { Pro Go Fitness } \\
\text { Space }\end{array}$ & 全时优健 & Experience Service & No matches & 禁止带火种 & Safety Warning \\
\hline ade & 果汁饮料 & Beverages Sign & No Smoking & 禁止抽烟 & Safety Warning \\
\hline Functional drink & 功能性饮料 & Beverages Sign & $\begin{array}{l}\text { No flammable } \\
\text { materials }\end{array}$ & 禁止放易燃物 & Safety Warning \\
\hline $\begin{array}{l}\text { Coffee-based } \\
\text { beverage }\end{array}$ & 咖啡饮料 & Coffee Sign & No burning & 禁止烟火 & Safety Warning \\
\hline Milk tea beverage & 奶茶饮料 & Beverages Sign & Fire Extinguisher & 灭火器 & Safety Warning \\
\hline Soda water & 苏打水 & Beverages Sign & $\begin{array}{c}\text { Manual Activating } \\
\text { device }\end{array}$ & 消防手动启动器 & Safety Warning \\
\hline Soda pop & 碳酸饮料 & Beverages Sign & $\begin{array}{c}\text { Fire-fighting } \\
\text { equipment }\end{array}$ & 灭火设备 & Safety Warning \\
\hline $\begin{array}{c}\text { Fresh Chicken } \\
\text { Parts }\end{array}$ & 黄羽鸡部位肉 & Food Sign & $\begin{array}{l}\text { Fire Hydrant alarm } \\
\text { button }\end{array}$ & 火栓报警按钮 & Safety Warning \\
\hline Savory Pork & 草香猪 & Food Sign & exit & 紧急出口 & Safety Warning \\
\hline Organic Beef & 新疆有机牛肉 & Food Sign & No entrance & 禁止入内 & Safety Warning \\
\hline $\begin{array}{l}\text { Fresh Delightful } \\
\text { Tasty }\end{array}$ & & Food Sign & No obstructing & 禁止阻塞 & Safety Warning \\
\hline Chinese Pancake & 蔬果煎饼 & Food Sign & No locking & 禁止锁闭 & Safety Warning \\
\hline $\begin{array}{l}\text { Canton Classic } \\
\text { Chicken Hot Pot }\end{array}$ & 广州芳村榕树头 & Food Sign & No littering & 禁止丢杂物 & Safety Warning \\
\hline $\begin{array}{l}\text { Bengong's Tea } \\
\text { Chinese Style }\end{array}$ & 本宫的茶 & Beverages Sign & No through road & 禁止通行 & Safety Warning \\
\hline New Feel & 新派烤肉 & Food Sign & Lukfook & 六福珠宝 & Watch/Jewelry \\
\hline FEDELAO & 豆捞坊 & Beverages Sign & Chow Tai Fook & 周大福珠宝 & Watch/Jewelry \\
\hline $\begin{array}{l}\text { Designer Cake } \\
\text { Shop }\end{array}$ & 阶芝墨 & Beverages Sign & & & \\
\hline
\end{tabular}

